\title{
„Húsz év múlva” \\ - A digitális oktatás helyzete, eszközei, trendjei világszerte
}

\author{
Fehér Péter \\ IKT MasterMinds Kutatócsoport
}

\begin{abstract}
Absztrakt
A tanulmányban - egy 20 évvel ezelőtti munkánkra reflektálva (Fehér, 1999)- széleskörü áttekintést adunk a digitális oktatás jelenlegi helyzetéről. Kiemelt figyelmet szentelünk a témakör legfontosabbnak ítélt témáira: a mobiloktatásra, a kódolás-számítógépes gondolkodás és robotika témájára, a digitális történetmesélésre, valamint a médiaműveltség és a kritikus gondolkodás fontosságára. A nagy mennyiségű külföldi irodalom elemzése mellett kitérünk a hazai kutatások ismertetésére, a digitális oktatás nemzetközi és magyarországi eredményeinek, kihívásainak bemutatására.
\end{abstract}

Kulcsszavak: digitális oktatás, mobiloktatás, kódolás, digitális történetmesélés, trendek

\section{Bevezetés}

Egy 1999-ben megjelent tanulmányban (Fehér, 1999) széleskörủ áttekintést adtunk az IKT oktatásbeli használatának nemzetközi és hazai helyzetéről, és közreadtuk neves szakemberek néhány, jövőre vonatkozó „jóslatát” is. Mostani írásunkban kísérletet teszünk arra, hogy 20 év elteltével újra megvizsgáljuk az azóta történt változásokat, bemutassuk, merre és hogyan fejlődött az akkori cikkben is megemlített digitális pedagógia.

Különös figyelmet fordítottunk arra, hogy a legfrissebb hazai és külföldi empirikus kutatásokból is merítve képet kaphassunk arról, melyek a meghatározó trendek világszerte, a nálunk nagyobb erőforrásokkal rendelkező, vagy más szempontból előrébb tartó országokban. Ugyanakkor törekedtünk arra is, hogy az egyes témákhoz kapcsolódó magyar kutatásokat, eredményeket is megemlítsük, feltárva a nemzetközi trendekhez való kapcsolódás lehetőségeit.

A digitális pedagógia mára túljutott azon a szinten, hogy az eszközökhöz való hozzáférés biztosítaná a jobb tanulási eredményeket. 2020-ban már az is tudható, hogy a digitális oktatás nem csupán a módszerek digitalizálását jelenti, hanem a folyamat digitális eszközök bevonásával történő kiegészítését, gaz- 
dagítását és újragondolását (Davis, 2020). A kutatók egyetértenek abban, hogy 2020-ban a legfontosabb kérdés az „hogyan lehet a technológia használatát a tanulás hatékonyságának növelése érdekében maximalizálni, a differenciált tanítást támogatni, a diákok figyelmét fokozni, kitartásukat növelni, valamint motivációjukat fenntartani (Molnár, Turcsányi-Szabó \& Kárpáti, 2020).

\section{A mobil tanulás előretörése}

Amíg a 2000-es évek elején az internet hozzáférés, az internetes információforrások, oktatási portálok létrehozása volt az egyik fő témája az IKT alkalmazási lehetőségeivel kapcsolatos kutatásoknak, 2010 körül a mobil eszközök (netbook, notebook, okostelefon, táblagép, elektronikus könyvolvasó) előretörésével a hangsúly abba az irányba tolódott el, hogy miként befolyásolhatja a tanulást (és az oktatást) a mindenhol elérhető eszközök megjelenése (Balanskat \& Garoia, 2010). A tanulás formális keretei közül kilépve nagy szerepet jósoltak az informális tanulásnak, amikor a tanulók helytől és időtől függetlenül, nem feltétlenül szándékolt tanulási célzattal tesznek szert új tudásra, sajátítanak el új kompetenciákat (az e-learningtől kezdve az u-learningen keresztül).

Több országban indultak állami támogatású projektek, amelyek keretében táblagépekkel szerelték fel az iskolákat. Ezek vizsgálata meglehetősen heterogén képet mutat, pozitív és negatív kimenetelü implementációkra egyaránt találhatunk példákat. Czékmán (2019) tanulmányában megállapítja, hogy a sikeres projektek között említhetők Dél-Korea IKT-val támogatott kezdeményezései, az utóbbi évtized legnagyobb technológiai projektje, a törökországi „FATİH”, a „One Laptop Per Child” (OLPC) nemzetközi kezdeményezése, valamint az Egyesült Királyság területén indított számos, kisebb projekt. A pozitívumok mellett ugyanakkor a projektek több esetben kudarccal végződtek, melynek okai között a nem megfelelő tervezés és előkészítés, az alkalmazott eszközök minősége (lásd Aakash, India), a finanszírozási séma, a digitális tartalmak megléte, minősége, alkalmazása, és legtöbb esetben a pedagógusok felkészítése, hozzáállása, vagy éppen a nem megfelelő módszertan (lásd Hollandia) szerepelt (Czékmán, 2019, p. 486). További sikeresen megvalósított táblagépes kezdeményezésekre láthatunk példát Skóciában és Walesben (Clark \& Luckin, 2013; Fehér, 2018c).

Bár Magyarországon nem került sor komoly módszertani háttérrel megtámogatott kormányzati táblaképes projekt megvalósítására, az iskolák egy része kapott táblagépeket. Ezzel kapcsolatos felmérés vagy kutatási eredmény jelenleg nem áll rendelkezésre, személyes visszajelzések alapján nem volt problémamentes a folyamat (az iskolai használat tervezettségének hiányosságai, módszertani felkészítés hiányosságai, elavult táblagépek beszerzése stb.).

Hazánkban mindenekelőtt Czékmán Balázs (2017) kutatásait kell kiemelnünk, aki a táblagépek iskolai alkalmazását kutatja, az intézményi implementációtól kezdve az egyes tantárgyak tanításába történő integrációig. Kollégáival együttműködésben megvalósított iskolai integráció (amely a Kispesti 
Puskás Ferenc Általános Iskolában folyik immár több, mint öt éve) eredményei azt mutatják, hogy a mobileszközök használatának eredményes iskolai bevezetéséhez jóval többre van szükség, mint maguknak az eszközöknek a rendelkezésre bocsátása. A mobil eszközök iskolai alkalmazásának bevezetésében jelentős szerepet játszottak olyan üzleti szereplők is, mint például a Samsung (SmartSchool program), a Telenor (HiperSuli program), Vodafone (Digitális Iskola program). Ezen programok szintén meghaladják az „eszköz osztogatás" szintjét, és rendelkeznek a megfelelő szakmai-tudományos háttérrel, fontos lenne eredményeik széles körben történő közreadása.

A digitális eszközök beszerzésére fordítható költségvetési keretek szükössége miatt már évek óta emlegetik a lehetséges megoldások közt a BYOD (Bring Your Own Device - Használd a saját eszközödet) módszert, amely a tanulók által birtokolt saját eszközök iskolai használatát tenné lehetővé, azonban a gyakorlatban továbbra sem látszik előrelépés ezen a területen. Ennek legfőbb oka nem a diákok eszközhiánya, sokkal inkább a szabályozottság hiánya lehet, amit a jelenlegi központosított rendszerben meglehetősen nehéz megoldani.

Egy másik jelentős kihívás, amellyel a mobil eszközök használata során szembe kell nézni, az eszközhasználat „korlátozhatatlansága”, amelyből számos negatív hatás vezethető le. Egyes országokban (például Nyugat-Ausztrália, Franciaországban állami szinten, az Amerikai Egyesült Államokban és az Egyesült Királyságban az egyes iskolák vezetősége kezébe helyezve a döntést) már olyan intézkedéseket hoztak, amelyek egyenesen megtiltják az okostelefonok iskolai használatát. Olyan kérdések merültek fel például, hogy milyen tudományos érvekkel igazolhatók az ilyen és hasonló intézkedések.

Beland és Murphy (2015) komoly apparátuson alapuló kutatása szerint az okostelefonok iskolai jelenléte számos negatív hatással jár a tanulók teljesítményére. A 91 nagyvárosi iskola tanulóit vizsgáló kutatás legfontosabb eredménye, hogy a telefonok kitiltása után 14\%-kal (!!) emelkedett a gyengén teljesítők eredménye, a jól teljesítők eredménye lényegében nem változott. Véleményük szerint a legolcsóbb megoldás a tanulás esélyegyenlőség megvalósítására a mobiltelefonok kitiltása lehet. Ugyanakkor azt is leszögezik, hogy ez nem jelenti a megfelelően tervezett és kivitelezett oktatási célú alkalmazás hasznosságának kétségbe vonását.

Röviden összegezve az elmondottakat, az empirikus vizsgálatok azt mutatják, hogy „a táblagépek sikeres iskolai bevezetése körültekinto és hosszú távú tervezést igényel, a bevezetés folyamata előtt, közben és utána egyaránt" (Clark-Luckin, 2013). Ezt erősítik meg a már említett hazai eredmények is.

\section{A valóság kitágítása}

\section{- A virtuális és kiterjesztett valóság eszközeinek megjelenése}

A mobileszközök térhódítása eddig kiaknázatlan lehetőségeket tárt fel a 3D-s immerzív (bemerüléses) virtuálisvalóság-alkalmazások és a kiterjesztettvalóság-applikációk oktatási alkalmazásával kapcsolatban is. A korábban csak a 
számítógépek képernyőjén megelevenedő virtuálisvalóság-környezetek (például a világszerte népszerű Second-Life) a közelmúltban elérhetővé váltak különböző árkategóriába eső 3D-szemüvegek (Microsoft HoloLens, Google Glass, Google Cardboard, Oculus Rift, Sony, Samsung Gear VR és mások) segítségével gyakorlatilag bárki számára lehetőséget biztosítanak a háromdimenziós világban történő kalandozásra, vagy akár, a megfelelő tananyagok használata esetén, a tanulásra is. Milyen előnyöket rejt ez a technológia az oktatás világa számára? Miért tekinthetők hasznosnak a pedagógia számára? Milyen kihívásokkal kell megküzdeni? A kutatási eredmények összegzése (Ferdig, Gandolfi \& Immel, 2018) alapján a virtuális valóság alkalmazások az oktatás nagyon széles spektrumában alkalmazhatók. A közoktatásban például a történelem, földrajz, nyelvoktatás vagy akár a természettudományok és a művészettörténet tanítása során, a felsőoktatásban például az orvostudomány (annak részterületei), építészeti tervezés, az alkalmazott számítástechnika és számos más területen. Egy középiskolai, természettudományos témájú oktatásban alkalmazott VR-alkalmazásokat vizsgáló kutatásokat szemléző tanulmány szerint a virtuális valóság használata ezekben az esetekben növelte a tanulók motivációját, aktivitását, és alapot biztosít a konstruktív elveken nyugvó, felfedezéses tanulásra (Radianti, et al., 2019; Czekman, Aknai \& Feher, 2017a).

Ezzel együtt a kutatók számos olyan kérdést is felvetnek, amelyek problematikusak lehetnek az oktatási alkalmazás szempontjából. Megállapításuk szerint a virtuális valóság alkalmazása csak megfelelő körülmények és feltételek fennállása esetén jár pozitív tanulási eredményekkel. Az alkalmazás lehetséges problémái között említik a kognitív túlterhelést vagy akár hosszabb távon különböző fizikai hatásokat (szédülés, dezorientáció, hányinger) is. A technikai jellegű problémák között a hozzáférés és az egyes alkalmazások változékonyságát kell figyelembe venni, erre a legjobb példa a HP Reveal (korábban Aurasma) néven népszerű kiterjesztettvalóság-alkalmazás megszűnése, amely azóta sem helyettesíthető könnyen (ingyenesen), ez pedig komoly gondot okoz az azt használók számára.

Kriskó (2017) ugyanakkor felhívja a figyelmet arra is, hogy számos etikai és pszichológiai szempontot is figyelembe kell vennünk az VR-technológia (nem elsősorban oktatási, de arra is vonatkoztatható) alkalmazása esetén, mert ezek negatív hatásokkal is járhatnak. Ilyenek például a virtuális bántalmazás (pszichológiai kínzás), szenzoros túlterhelés, függőség előidézése és mások.

A kiterjesztett valóság (Augmented Reality) esetében a virtuális valóságtól némileg eltérően nem egy virtuális térben „merül el” a felhasználó (jóllehet egyes szerzők az AR-t a VR részhalmazaként definiálják), hanem a valóságos világ objektumai egészülnek ki virtuális elemekkel. Ennek használatához a már említett VR-szemüvegek, vagy leggyakrabban okostelefonok és táblagépek használhatók.

Nézőpontunk szerint pedagógiai szempontból nagyobb jelentőséggel bírnak, mivel meghaladva az alapszintű szemléltetés, tartalomfogyasztás, 
és a haladóbb szinten esetleg megvalósuló felhasználók közötti interakciók lehetőségeit, a kiterjesztett valóság több lehetőséget kínál a tanulók számára az önállóan vagy csoportban végzett alkotó tevékenységre, kiterjesztett valóság alkalmazások létrehozására. Ezen a területen Aknai, Czékmán és Fehér empirikus, iskolai környezetben végzett pilotkutatásaiból tájékozódhatunk (Fehér, Czékmán \& Aknai, 2016; Czémán, Aknai \& Fehér, 2017a). Eredményeik szerint „az AR órán való felhasználása felkelti az érdeklődést, míg önálló elkészítése a belső motivációt erősíti, a tanuló önállóan, saját gondolatai és ötletei alapján alkot" (Czékmán, Aknai \& Fehér, 2017b, p. 21).

Az AR és VR-rel kapcsolatos kutatások eddigi eredményeit összegezve azt emelnénk ki, hogy a jelenleg még gyakran komoly akadályt képező technikai nehézségek leküzdése mellett a pedagógiai hatékonyság kérdései is komoly empirikus kutatásokat igényelnek. Radianti és munkatársai kutatása szerint a VR felsőoktatásbeli alkalmazásait bemutató tanulmányokban alig jelenik meg utalás a fejlesztések alapjául szolgáló oktatáselméleti meggondolásokkal kapcsolatban, és hasonló kijelentést tesznek a tanulási eredmények vonatkozásában is (Radianti, Majchrzak, Fromm \& Wohlgenannt, 2019). Egyet kell értenünk azzal a konklúzióval, mely szerint „az immerzív VR leginkább kísérleti és fejlesztési fázisban lévó munka, mint a jelenlegi oktatásban rendszeresen alkalmazott eszköz" (Radianti et al., 2019, p. 1). Hasonló a helyzet az AR-alkalmazások és a közoktatásbeli felhasználások terén is, ugyanakkor az AR és VR-ben lévő óriási üzleti potenciál, amelyet az elkövetkezendő évekre vonatkozó üzleti előrejelzésekből látható (Global Augmented Reality, 2019), tág teret engednek az oktatási célú felhasználásnak is. A legfrissebb fejlesztések arra irányulnak, hogy a 3D-szemüveget olyan szenzorokkal bővítsék, amelyek tovább növelik a felhasználói élményt.

\section{Digitális történetmesélés mint a komplex kompetenciafejlesztés lehetősége}

A digitális történetmesélés az IKT-oktatásbeli alkalmazások talán legbővebb lehetőségeit magában foglaló módszer. A digitális történetek elkészítése során (akár egyéni, akár kollaboratív csoportmunkában) a tanulók aktív, kreatív tevékenységére van szükség, amely támogatja a NAT-ban is szereplő kompetenciák integrált és komplex fejlesztését ${ }^{1}$.

Ha a digitális történetmesélés fogalmának egy lehetséges legbővebb értelmezését tartjuk szem elött, mely szerint a DS (digital storytelling, digitális történetmesélés) egy olyan tantermi (és akár tanórán kívül is megvalósítható) módszer, amely a történetek elmeséléséhez a multimédia eszköztárának széles körét használja fel, akkor könnyen érthetővé válik, hogy a módszer

\footnotetext{
${ }^{1}$ A kommunikációs kompetenciák, az anyanyelvi és idegen nyelvi kompetenciák, a személyes és társas kapcsolati kompetenciák, valamint a kreativitás, a kreatív alkotás, önkifejezés és kulturális tudatosság kompetenciái mellett, a digitális kompetenciára alapozva.
} 
alkalmazása nem kötődik sem tantárgyhoz, sem életkorhoz. A módszert az 1990-es évek elején dolgozták ki az Egyesült Államokban, és azóta világszerte rengetegen használják, az oktatás legkülönbözőbb területein (és az oktatáson kívül is).

Hazánkban is több példát találhattunk már a 2000-es évektől kezdve, óvodás és kisiskolások (Pasaréti, 2009; Turcsányi-Szabó \& Pasaréti, 2010), valamint az általános iskola felső tagozatosai körében is (Fehér, 2008, 2010). A digitális történetmesélés és a kiterjesztett valóság összekapcsolásának lehetőségét vizsgálták Fehér és munkatársai a már korábban említett általános iskolai akciókutatás keretében (Fehér et al., 2016; Czékmán et al., 2017b) és az alkalmazás lehetőségeit más tárgyak esetében (Fehér, 2017b). Lanszki és munkatársai kutatásai (Lanszki, 2017) eredményeképp immár magyarul is elérhető a digitális történetmesélés módszertanát és gyakorlati felhasználhatóságát bemutató kötet, illetve a Tempus Közalapítvány által támogatott módszertani anyagokat tartalmazó gyüjtemény².

A digitális történetmeséléssel kapcsolatos kutatások aktuális helyzetét kutatva Wu és Chen (2020) 57 tanulmányt vizsgáltak át, hogy feltárják a digitális történetmesélés aktuális trendjeit és a vele elért eredményeket. Megállapításaik szerint a digitális történetmesélés népszerűsége töretlenül fejlődik világszerte, az általános iskolától a felsőoktatásig minden szinten fellelhetők a felhasználási területei, többnyire, de nem kizárólagosan, a humán és társadalomtudományi témákban. Az empirikus kutatások során a téma kutatói az esetek többségében kvalitatív és kevert módszereket használnak, ennek ellenére elmondható, hogy a kapott eredmények pozitívak.

A digitális történetmesélés alkalmazásával szemben leginkább két fó akadályt kell figyelembe venni és leküzdeni: a tradicionális óraszervezés rendszerét és a szükséges digitális kompetenciák hiányát. A kínálkozó lehetőségek közül a projektalapú tanulás szervezési mód javasolható, amelyre a különböző iskolai témahetek (lásd később) kínálnak adekvát megoldást.

\section{Kódolás, a számítógépes gondolkodás és a robotika}

A számítógépek oktatásbeli felhasználásának történetét áttekintve (a magyarországi történéseket lásd például Czékmán \& Fehér, 2017) azt látjuk, hogy időről időre hangsúlybeli változások történtek, amelyek csak részben magyarázhatók a technológia változásával, ugyanakkor a humán tényezők szerepe sem elhanyagolható. Az 1980-as években, a személyi számítógépek megjelenésének és széles körű elterjedésének idején az oktatásbeli felhasználás elsősorban a gépek programozásának elsajátítását célozta meg.

Az 1990-es éveket a multimédia évtizedének tekinthetjük, ahol óriási mennyiségben keletkeztek olyan tananyagok, amelyek a számítástechnikán túlmenően a többi tantárgy óráira szerették volna bevinni a számítógépeket.

${ }^{2}$ https://tka.hu/nemzetkozi/6577/digitalis-tortenetmeseles 
A '90-es évek második felében, az internet és a web megjelenésével egyrészt megkezdődött ezen anyagok „webre költöztetése” nemzeti és nemzetközi oktatási portálok, repozitóriumok formájában, majd a 2000-es évek elején, a web2 születése után ez kibővült a személyes kommunikáció és a személyes tartalomfejlesztés lehetőségeivel. A hordozható eszközök elterjedése a 2010es évek elején kezdődött, és a netbookok, notebookok mellett az okostelefonok és táblagépek megjelenése jelentősen megváltoztatta az információkhoz való viszonyt és a hozzáférést.

Ezzel csaknem egy időben arra figyeltek fel a kutatók, hogy a tanulók számítógépes (vagy ha úgy tetszik informatikai) tudása elmarad a jóslatoktól, valamint a munkaerőpiac kívánalmainak sem felel meg. Az első vészharangot az angol Royal Society kongatta meg 2012-ben, ahol a világszerte széles körben elterjedt „IKT alkalmazása az oktatásban” megközelítés helyett az egyre kisebb hangsúllyal szereplő kódolás, problémamegoldás és programozás fontosságára hívta fel a figyelmet (Royal Society, 2012). Az addig töretlen népszerüségre szert tett generációs elméletről az empirikus kutatásokat áttekintve egyre inkább kiderült, hogy nem állja meg a helyét - a diákok számítógépes tudása messze elmarad az optimista jóslatokban leírt és kívánatos szinttől. A tanulmány megállapításai szerint

- A nemzeti alaptanterv szerinti IKT tanterv nagyon széleskörü szabadságot tesz lehetővé, és olyan alacsony szintre csökkenheti a követelményeket, hogy azokat a szükséges végzettséggel nem rendelkező tanár is elláthatja.

- Ezzel egyidejüleg hiány mutatkozik olyan tanárokban, akik a digitális írástudáson túlmenő ismereteket képesek tanítani.

- Hiányzik a folyamatos professzionális továbbképzés háttere a számítástechnika tanárok számára.

- Az iskolai infrastruktúra hiányosságai hátráltatják a számítástechnika hatékony oktatását.

A jelentés felhívta a döntéshozók figyelmét a számítástechnika, a számítástudomány, az információtechnológia és a digitális írástudás fogalmai közötti különbségtétel fontosságára, megadva ezek definícióit is (Fehér, 2018c). Az új tanterv bevezetése óta elért változásokat a Royal Society második jelentés tartalmazza (Royal Society, 2017).

Mindezek alapján úgy tünik, hogy visszatértünk a kiindulási pontra, ismét kiemelt hangsúlyt kell szentelni az informatika oktatásában a problémamegoldó és az algoritmikus gondolkodásnak és a programozás alapjai elsajátításának. Világszerte megkezdődött az informatika (és IKT) oktatást szabályozó curriculumok vizsgálata és módosítása, és 2015-re az EU-s országok többsége igyekezett határozott lépéseket tenni abba az irányba, hogy a kódolás és programozás elemei bekerüljenek a nemzeti tantervekbe. Az EU erre vonatkozó kezdeményezéseiről Balanskat és Engelhardt (2014; 2015) felméréseinek leírásában olvashatunk. Magyarország - valamilyen okból kifolyólag - az első körben nem szerepelt a résztvevők között, csak a második 
felmérésben olvashatunk róla adatokat.

„A kódolás az új írástudás!" - állítja Mitch Resnick (2015), a programozás megkedveltetését és népszerűsítését szolgáló blokkalapú programozási nyelv, a Scratch egyik létrehozója (Resnick, 2015). Az MTI MediaLab professzora kutatásaira alapozva azt állítja, hogy a kódolás a 21. századi képességek egyik mindenki számára alapvetőnek tekinthető összetevője. A kódolás megtanulásához a következő négy alapelvet határozzák meg:

1. Projektek (Projects): a kódolás elsajátítása értelemmel bíró projekteken keresztül történjen.

2. Társak (Peers): a tanulás során közösen, tudásokat egymással megosztva dolgozzanak a tanulók.

3. Szenvedély (Passion): a diákok a saját érdeklődési körüknek megfelelő projekteken keresztül tevékenykedve hatékonyabban tudnak tanulni.

4. Játékosság (Play): a kódolás tanulása során a diákok szabadon kísérletezhetnek a feladatok megoldásával, új dolgokat próbálhatnak ki, tanulhatnak a megoldás keresése során elkövetett saját hibáikból, és azok kijavításából (Resnick \& Siegel, 2015).

Állításának lényege nem az, hogy mindenkinek programozóvá kellene válnia, hanem annak a meggyőződésnek az elterjesztése, hogy a kódolás megtanulása hozzásegítheti a tanulókat az önkifejezés új formáinak megtalálásához, kreativitásuk és gondolkodásuk fejlesztéséhez.

Meg kell említenünk még egy fogalmat, amely áthatja az ebben a szakaszban ismertetett téma egészét: a számítógépes gondolkodás (computational thinking). Az eredetileg Seymour Papert nevéhez füződő elnevezést Jeanette Wing (2006) cikkének megjelenése után vált széles körben ismertté, és napjainkban az egyik legtöbbet emlegetett és kutatott fogalmává a digitális oktatás kódolással és robotikával kapcsolatos diskurzusainak. Wing eredeti definíciója szerint „a számítógépes gondolkodás magában foglalja a problémák megoldását, a rendszerek tervezését, és a humán viselkedés megértését, a számítástudomány alapelveire támaszkodva" (Wing, 2006, p. 33). Az azóta eltelt években ezt a definíciót számos kutató árnyalta és pontosította (például Fehér, 2017a; 2018d), és jelentős számú empirikus kutatás történt a gyakorlatban való alkalmazás lehetőségeinek feltárására.

A kódolás és programozás megszerettetésének és megtanulásának motivációs bázisaként, másrészt a STEM-területek (Science, Technology, Engineering, and Mathematics) összekapcsolásának eszközeként tekinthetünk a lassan két évtizedes múltra visszatekintő, de napjainkban rohamosan fejlődő oktatási robotikára (educational robotics).

Fontos kiemelni, hogy a robotok iskolai alkalmazásának bevezetése nem egy öncélú tevékenységnek tekinthető, hanem pontosan meghatározott célokkal történik világszerte. Az oktatási robotika első lépései idején elsősorban a konstruktív pedagógia elveire épült, amelyek számítógépes oktatásban való alkalmazását Seymour Papert nevéhez kapcsolhatjuk. Papert ezt a konstrukcionizmus létrehozásával egészítette ki, amivel azt kívánta modellezni, 
hogyan alkotnak dolgokat a gyerekek egymás és a technológia segítségével. A 2000-es évek közepén lassan fejlődésnek induló kutatási területen kezdetben többnyire kvalitatív beszámolók voltak túlnyomó többségben, így érthető, hogy Alimisis (2013) helyzetértékelésben az egyik legfontosabb feladatként az empirikus, kvantitatív méréseken alapuló bizonyítékokat sürgette a robotok iskolai felhasználása kapcsán.

A kisgyermekek tanulásával kapcsolatos kutatások szerint robotokkal való ismerkedés már óvodáskorban elkezdődhet. Beers (2008) kutatásai szerint már a négyévesek képesek lehetnek egyszerű robot megépítésére és irányítására. Ugyanakkor azt is sikerült kimutatniuk (Sullivan \& Bers, 2012), hogy óvodás életkorban még nincs szignifikáns különbség a lányok és fiúk teljesítménye között, sem a robot építésében sem a programozása terén, ami azért fontos, mert igazolja azt az állítást, hogy a gendersztereotípiák kialakulása nélkül a gyerekek nemtől függetlenül képesek hasonló eredmények elérésére. Bizonyára ezeknek is köszönhető az, hogy fejlesztők által megalkotott padlórobotok már az óvodások számára készített eszközökkel kezdődnek a játékos oktatási eszközök piacán. Az ezzel kapcsolatos kutatásokról részletes képet kaphatunk Bers könyveiből (Bers, 2008; 2018). Az idősebbek (felső tagozatosok, középiskolások) esetében komplexebb eszközök és feladatok alkalmazására kerülhet sor. Külön meg kell említenünk, hogy egyre több kutatás áll rendelkezésre az SNI diákok tanulásának robotikai eszközökkel történő támogatásával kapcsolatban, ezt részletesebben tárgyalja Aknai \& Fehér (2019).

A robotika oktatásának bevezetését számos tényező nehezíti, ilyenek például az eszközök magas ára, használatukhoz szükséges speciális tudás (programozás), és esetenként a tanórai integráció. Valószínủleg ezek az okok is közrejátszanak abban, hogy a hazai helyzet a robotok tanórai és iskolai használata szempontjából is felemás. Pontos felmérések hiányában nem lehetséges egzakt számokat megadni, az iskolák hányadrészében találhatók meg azok a robotikai eszközök, amelyekről a Digitális Oktatási Stratégiában $^{3}$ olvashattunk. Annyi elmondható, hogy az alsó tagozatos oktatásban egyre több helyen érhetők el padlórobotok (a legelterjedtebbek a Bee-Bot, Blue-Bot, Ozobot, Edison, mBot), bár ezeket az esetek jelentős részében nem központi, vagy állami finanszírozásból kerülnek a tantermekbe, hanem sok esetben a pedagógusok saját eszközei.

Itt feltétlenül említést kell tennünk azokról a hazai „multiplikációs kísérletekről", amelyek nemzetközi szinten is érdekes megoldásnak tünnek (Fehér \& Aknai, 2019). A robotok korlátozott hozzáférhetősége miatt több olyan egyéni kezdeményezés is született hazánkban, amelyek keretében robotikai eszközök juthatnak el az ilyenekkel nem rendelkező iskolákba (például Robotcsámborgás - Fári János, Micro:bit botorkálás - Abonyi-Tóth Andor és

${ }^{3}$ DOS 2016 Magyarország Digitális Oktatási Stratégiája. A Kormány által 1536/2016. (X. 13.) Korm. határozattal a Digitális Jólét Program részeként elfogadott stratégia. https://www. kormany.hu/download/0/cc/d0000/MDO.pdf 
Edison-Futamaz egyes eszközök forgalmazóinak támogatása révén (Aknai \& Fehér, 2019).

Az említett padlórobotokon kívül a legjelentősebb szerepet a LEGO Mindstorms EV3 robotok képviselik, amelyek a tehetséggondozás keretében különböző hazai és nemzetközi robotikaversenyeken (ezek közül a legismertebbek a WRO - World Robot Olympiad, FLL - First LEGO League, részletesen lásd Kiss, 2014) való részvétel lehetőségét biztosítják hazánkban is, több mint 15 éve. Ezeken a világversenyeken évről évre kiemelkedő teljesítményeket érnek el a hazai diákok, sajnálatos, hogy az ebben résztvevők száma erősen korlátozott, elsősorban az eszközök magas ára és a tanári innováció hiánya miatt (Kiss, 2014). Empirikus kutatásai azt is bizonyítják, hogy „a választott programozás-oktatási eszköz, a LEGO cég MINDSTORMS robotjai alkalmasak a tanórai használatra, az algoritmikus gondolkodás fejlesztésére. A bennük rejlő kreatív lehetőségek a természettudományos oktatás új alapokra helyezését is elősegíthetik. A motivációs szerepük viszont meghaladja a „hagyományos” programozás-oktatásban eddig használt eszközökét." (Kiss, 2014, p. 89).

A LEGO-robotok programozásán keresztül kapcsolatot teremthetünk a másik preferált digitális pedagógiai témával, a STEM-oktatással. Kiss Róbertet idézve: „Már nem sci-fi kategória az olyan autó, amelyik sofőr nélkül képes leparkolni, vagy a vezető nélküli metrószerelvény. Ezek mögött ott van az emberi intelligencia mérnöki kreativitása. Hogy mindez ne tünjön holmi varázslatnak, a diákoknak is érdemes tudni az eszközök működése mögött meghúzódó algoritmusokról, érzékelőkről, elektronikus kommunikációs technológiáról. Nem kell, hogy mérnökök legyenek, de fontos, hogy lássák ezekben a mérnöki teljesítményt. Ebben segít a robotika, amely alkalmas az algoritmikus gondolkodás fejlesztésére, a műszaki szemlélet kialakítására." (Kiss, 2015). Ebbe az irányba történő próbálkozások a hazánkban is elinduló MakerSpace-ek, és ehhez nyújthat alapot az Egyesült Királyságból indult, és mára világszerte sikeresen, és széles körben használt Micro:bit. Az Egyesült Királyság példáját követve, ahol 2016-ban 1 millió darabot osztottak szét a hetedik osztályos diákok között, számos további ország kormánya is hasonló központi kezdeményezéseket indított el, például Horvátország, Dánia, Izland, Kanada, Norvégia, Szingapúr, Hongkong és mások. Az eszköz olcsósága, és a megjelenése óta kifejlesztett százas nagyságrendű kiegészítők kiválóan alkalmassá teszik a tanulók kreativitásának fejlesztésére (Fehér, 2017c; Czékmán-Kiss, 2018; Fehér, 2018; Austin et al., 2020).

A fentieket összefoglalva azt mondhatjuk, hogy a számítógépes gondolkodás fejlesztése, a robotika és kódolás eszköztárának hatékony kihasználásával, alkalmasnak látszik a STEM oktatás céljainak megvalósítására. Ehhez azonban eszközök, kutatások, kreativitás és innováció szükséges a főszereplők: a diákok és tanárok részéről egyaránt. 


\section{Médiamüveltség és kritikai gondolkodás a fake-news korában}

Az előző részben tárgyalt kódolás, programozás, robotika és a STEM elsősorban a reál területekkel kapcsolatos gondolkodásfejlesztési kérdéseket foglalja magában, a mostani szakaszban a nem kevésbé fontos humán megközelítések által megkövetelt tényezőket próbáljuk meg áttekinteni.

Az 1999-es tanulmányunkban egy hosszabb részt szenteltünk a netgenerációnak, akiket aztán két évvel később Prensky (2001) digitális bennszülöttekként aposztrofált, felruházva számos olyan tulajdonsággal, amikről aztán bebizonyosodott, hogy a mítosz kategóriába sorolhatók. Prensky cikke világszerte nagy hatást gyakorolt mind a kutatókra, mind a pedagógusokra, nagy vitákat váltott ki, míg a 2010-es évek után az empirikus eredmények hatására (Fehér-Hornyák, 2011; Tóth-Mózer \& Kárpáti, 2016; Tóth-Mózer, 2017; Tóth-Mózer, 2018) jóval árnyaltabbá vált az általa felvázolt digitális bennszülött-digitális bevándorló ellentétpár (Koltay, 2016), és letisztult, empirikus bizonyítékokon alapuló képet kaptunk az úgynevezett generációs elméletek egyes jóslatairól. Hasonlóan negatív válaszokat adott az empirikus kutatás például egy másik népszerü mítoszról, az új generációk „multitasking” képességeivel kapcsolatban. Ellis és munkatársai (Ellis et al., 2010) 62, üzleti tanulmányokat folytató diákot, Matthew (2015) 91, betegápolást tanuló hallgatót vizsgált, és az eredmények azt mutatták, hogy a „multitaskoló” diákok eredménye szignifikánsan gyengébb a csupán egy feladat elvégzésére koncentráló diákokénál. 2018-ban May és Elder kiterjedt irodalomkutatáson alapuló (38 tanulmányt vizsgáló) kutatása véleményünk szerint egyértelmüvé tette, hogy a diákok körében szokásosnak tekinthető multitasking jellegü tevékenység jelentősen rontja a diákok tanulási eredményeit, negatív hatással van az olvasásértésre és jegyzetelésre, valamint az önszabályozásra (May \& Elder, 2018).

Szabó Éva pszichológus hasonló gondolatokat vet fel egy interjúban a 21. századi oktatás kihívásaival kapcsolatos kérdés kapcsán: Az egyik legfontosabb a digitális fejlődés által kiváltott idegrendszeri változások, figyelmi kapacitásbeli jellemzők és információfeldolgozási sajátosságok változása. Ennek a témának mára már széles szakirodalma van, amely azonban elsősorban a közoktatásra fókuszál, tekintve, hogy a digitális generáció problémái még csak most kezdenek elérni a felsőoktatás szintjére. Azonban pár éven belül [a felsőoktatásban is megjelennek] a tableteken, okostelefonokon és hypertexten nevelkedettek. Számukra a hagyományos oktatási forma nem lesz kellően figyelemfelkeltő és motiváló. Nehezen tudnak hosszasan élőbeszédre figyelni, a lineáris információfeldolgozás helyett a horizontális kerül előtérbe, a tisztán verbális helyét a képi információéhség veszi át. Ezen felül igénylik a folyamatos aktivitást, de lényegesen alacsonyabb a monotóniatürésük, mint a korábbi generációknak. Az információk kihámozása hosszabb szövegekből hypertext kiemeléses segítség nélkül rendkívül fáradtságosnak látszik, és szintén időigényes az úgynevezett „gyorsétterem szemlélet” nemcsak a 
hétköznapi viselkedésben, de az információszerzésben is előtérbe kerül. Keresik az előre feldolgozott, kivonatolt, mások által előkészített anyagokat, mint például a tanárok prezentációi vagy az interneten található különböző „segédanyagok”. Nem szívesen olvasnak és dolgoznak fel eredeti, nyers szövegeket, fárasztónak találják az olyan gondolkodási műveleteket, mint az összehasonlítás, kritikai elemzés, stb. A tanulás - különösen a bölcsész- és társadalomtudományi típusú tárgyak esetében - ehhez a rendszerhez nehezen fog alkalmazkodni, mert jellegében meglehetősen távol áll ettől (Szabó, 2017 idézi Füzi, 2018).

Ezek ismeretében nyilvánvaló, hogy át kell gondolni a digitális eszközök kontroll nélkül való használatának lehetőségeit, illetve hangsúlyosabbá kell tenni az önszabályozás és az önszabályozó tanulás elsajátítását.

A közelmúlt társadalmi történései több olyan jelenséget erősítettek fel (például az internethez való hozzáférés további kiszélesedése, az információkhoz való hozzáférés diverzifikálódása, a fake-news jelenség robbanásszerü térnyerése és mások), amelyek az eddiginél is fontosabbá teszik a médiaműveltség és a kritikus gondolkodás minél magasabb szinten történő elsajátítását, amit Koltay már 2011-es írásában sürgetett, számos kérdést felvetve a kritikus gondolkodást és a kritikus olvasást vizsgálva (Koltay, 2011). Ezek a kérdések cseppet sem avultak azóta. A valótlan információkkal, a szándékolt álhírekkel való megbirkózás érdekében az eddiginél lényegesen nagyobb figyelmet kell szentelni a közoktatásban és a felsőoktatásban is a médiamüveltség és a kritikus gondolkodás fejlesztésére, ami nem új tantárgyként kellene, hogy megjelenjen, hanem az oktatás teljes spektrumát átható tudás- és ismeretanyagként. Félő, hogy a hamarosan életbe lépő NAT digitális kultúra elnevezésü tárgyában szereplő órakeretek ehhez nem elégségesek.

\section{Pillanatkép a hazai helyzetről - eredmények és problématerületek}

Molnár, Turcsányi-Szabó \& Kárpáti (2020) közelmúltban megjelent tanulmányában több jelentős hazai eredményt mutatott be (a szegedi egyetemen kifejlesztett e-Dia, az ELTE Informatikai Kar T@T Laborjában végzett kutatási és fejlesztési tevékenységek, az MTA-ELTE Vizuális Kultúra Szakmódszertani Kutatócsoport előre mutató kutatási megállapításai stb.). Emellett említettük már a mobileszközök bevezetésében jelentős szerepet játszó HiperSuli, SMART School és Digitális Iskola programokat. Megjelent néhány új, korszerű ismereteket nyújtó és egyúttal friss kutatási eredményekről beszámoló konferencia (ezek közül említést érdemel a Balatonfüzfőn megrendezett Mobil eszközök az oktatásban és a kispesti Jelen és Jövő - Számítógépek és okos eszközök az iskolában, valamint az ELTE TÓK szervezésében a Robotika, kódolás kisgyermekkorban elnevezésủ rendezvény - mindhárom konferencia 4 alkalommal került megrendezésre, két évben rendeztek „Digitális Oktatási Konferencia és Kiállítás”-t a DPMK szervezésében). Két je- 
lentős, a közoktatás számára nagy jelentőséggel bíró esemény a Digitális Témahét és az Európai Unió-s kezdeményezéshez kötődő Kódolás Hete (Code Week).

Az EMMI és az IVSZ4 által kezdeményezett Digitális Témahét „fö célja a digitális pedagógia módszertanának népszerűsítése és elterjesztése a köznevelésben. A program fontos törekvése, hogy a digitáliskompetenciafejlesztés az informatikaórán túl kiterjedjen más tantárgyakra is. A résztvevő pedagógusok és diákok változatos és kreatív iskolai projektek keretében fejleszthetik képességeiket technológiával támogatott tanulás során." A 20162017-es tanévtől kezdve hivatalosan is bekerültek a témahetek (pénzügyi, digitális témahét és fenntarthatósági témahét) az EMMI által kiadott tanév rendjébe. A Digitális Témahetek sikerességét jelzi a közreműködő pedagógusok, diákok és megvalósult pedagógiai projektek száma. (1. táblázat)

1. táblázat

A digitális Témahéten résztvevők és projektek száma (Forrás: Fehér, 2018a)

\begin{tabular}{|l|l|l|l|}
\hline \multicolumn{1}{|c|}{ tanév } & \multicolumn{1}{c|}{ projektek száma } & résztvevő pedagógus & \multicolumn{1}{c|}{ résztvevő diák } \\
\hline $2015 / 16$ & 1932 & 5367 & 75000 \\
\hline $2016 / 17$ & 3241 & 7649 & 130000 \\
\hline $2017 / 18$ & közel 3000 & több, mint 7000 & 120000 \\
\hline $2018 / 19$ & több, mint 3000 & kevesebb, mint 8000 & 135000 \\
\hline
\end{tabular}

Ugyanakkor azt is figyelembe kell vennünk, a résztvevő pedagógusok száma nem növekszik dinamikusan, sok esetben évről évre ugyanazok a szereplők. Ha a közoktatásban résztvevő összes pedagógust vizsgáljuk, a digitális témahéten résztvevők száma az összes pedagógus létszámának mindössze 7\%-a.

A CodeWeek (a Kódolás Hete) egy önkéntesek által szervezett és müködtetett, az Európai Bizottság által támogatott közösségi kezdeményezés, melynek fő célja a kódolás, a programozás és a számítógépes gondolkodás népszerűsítése. 2019-ben az európai résztvevők száma meghaladta a 4 milliót. A rendezvény időszakában (ami igazából 2 hét) több ezer projekt rendezvényt szerveznek Európa-szerte, hogy a résztvevők megismerkedhessenek a programozás alapjaival, vagy magasabb szintjeivel akár. Magyarország a kezdetektől aktív résztvevője a Code Week-nek. (2. táblázat)

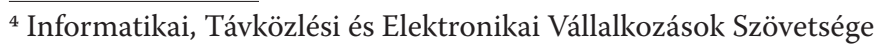


2. táblázat

Code Week aktivitás Magyarországon, 2014-2019 között

\begin{tabular}{|c|c|}
\hline Év & $\begin{array}{c}\text { Projektrendezvények száma } \\
\text { Magyarországon }\end{array}$ \\
\hline 2014 & 53 \\
\hline 2015 & 228 \\
\hline 2015 & 486 \\
\hline 2017 & 508 \\
\hline 2018 & 816 \\
\hline 2019 & 1330 \\
\hline
\end{tabular}

Mindkét rendezvényt roadshow- és webináriumformában szervezett gyakorlati felkészítések előzik meg és támogatják.

Mindezek azonban csupán a jéghegy csúcsát jelentik, a hazai digitális pedagógia élvonalába tartozó, illetve a "digitális módszerekkel megfertőződo”" pedagógusok találkozóhelyeinek tekinthetők. Innen kezdve már nem feltétlenül rózsás a kép. Nézzünk néhány problémásnak tekinthető területet. Ezekből a legkritikusabb a tanárképzés és a tanár-továbbképzések helyzete. A tanárképzés sajnos jelenleg sem készít fel minden pedagógusjelöltet a digitális eszközök eredményes és hatékony tanórai és tanórán kívüli használatának megtervezésére és a diákok maga szintü támogatására. Dringó-Horváth kutatási eredményei azt mutatják, hogy a kutatásban résztvevő oktatók IKT-aktivitása általánosságban, és a vizsgált oktatási módszerekhez kötődően is alacsony (Dringó-Horváth, 2018). A szerző megállapítja, hogy a technikai hiányosságok mellett „a módszertani hiányosságok állnak a háttérben, hiszen összességében kevés az oktatók tapasztalata a valóban modern, tanulóközpontú eszköz- és szoftverhasználatról, kevés saját élményük van mind tanulói előéletük, mind oktatói tapasztalatuk alapján az online tanulási tér kihasználásának lehetőségeiről, és sem intézményi támogatottságuk, sem pedig ilyen irányú előképzettségük nem tekinthető kielégítőnek" (Dringó-Horváth, 2018, p. 37-38.) Ez hasonló problémákat indikál a hallgatók oldaláról is. Második, a Károli Gáspár Református Egyetem tanár szakos hallgatói körében végzett pilotkutatásukban Dringó-Horváth és Gonda arra a következtetésre jutottak, hogy „mindenképpen több tanuló- és cselekvésközpontú taneszköz, tananyag és módszer alkalmazása lenne célszerü, és az esetlegesen beépített online- és blended-learning-elemek, valamint az IKT és/vagy a tanári IKT-kompetencia explicit fejlesztése konkrét kurzusok által várhatóan pozitívan hat a tanárjelölti IKT kompetenciájára" (Dringó-Horváth \& Gonda, 2018). A két eredmény nyilvánvalóan szorosan összefügg, hiszen a tanárjelöltek a tanulmányaik során kellene, hogy elsajátítsák az említett módszereket - amelyeket az oktatóik jelentős része sem használ. 
A tanár-továbbképzések helyzetét több változás is nehezítette a korábbi helyzethez képest. Az egyik ilyen az, hogy a pedagógusképzések önköltségessé váltak, amiket a fenntartó egyes esetekben támogathat, de ez általában nem jellemző. Ennek pozitív és negatív hatásai is vannak a pedagógusok szempontjából. Pozitívnak, motiválónak tekinthetjük abból a szempontból, hogy a képzésre vállalkozókat érdekeltebbé teszi a képzések elvégzésében, negatív lehet amiatt, hogy az elvégezni kívánt képzések kiválasztásánál azok költsége fontosabb szempont lehet a hasznosságuknál és minőségüknél. Jelentősen csökkent a szakmai rendezvényeken, konferenciákon való részvétel lehetősége, mivel sem ezek finanszírozása, sem az esetleges helyettesítés nem egyszerüen megvalósítható. Az esetek többségében a pedagógusok csak ingyenes rendezvényeken vesznek részt. Az említett korlátozó tényezők negatívan hatnak a pedagógusok szakmai önfejlesztésére, illetve az ezzel kapcsolatos motivációra. Egyre több tanárképzést szerveznek online- vagy blended learning formában (ilyen például a „Felkészítés a Köznevelési Regisztrációs és Tanulmányi Alaprendszer (KRÉTA) pedagógus moduljaihoz" című 30 kredites képzés), ezek minőségével és hatékonyságával kapcsolatos kutatási eredmények egyelőre nem állnak rendelkezésre.

Nagyon nehéznek mondható a helyzet az IKT-vel kapcsolatos kutatások tekintetében is, ha eredményeinket nemzetközi összehasonlításban vizsgáljuk (bár a tanárképzésben dolgozók IKT-kopmetenciáját tekintve már vannak próbálkozások, vö. Horváth et al., 2020). A közismert finanszírozási problémák miatt az IKT hazai kutatói közül nagyon kevesen tudnak részt venni a színvonalas nemzetközi együttműködésekben, a publikációk száma nagyon alacsony. (Ha az európai „éllovas országnak” számító Észtországgal vetjük össze, azt láthatjuk, hogy „az észt kutatók aktív szerepet játszanak az oktatással kapcsolatos nemzetközi kutatásokban, és az utóbbi években több rangos konferencia került megrendezésre Észtországban" (Fehér, 2018b).

Nem foglalkoztunk külön az olyan szokásos problémákkal, amelyek a digitális eszközbeszerzést vagy éppen a tanárok motivációjának növelését illetik, ezek mindegyike az aktuális kormányzat prioritásainak függvényei, így csak annyit említhetünk meg, hogy a 2016 júniusában előterjesztett, és a kormány által 2016 októberében elfogadott Magyarország Digitális Oktatási Stratégia (MDOS, 2016), valóra váltásának eddigi eredményei jelentős elmaradásban vannak a tervek megvalósításától (Horváth, 2018, 2019).

\section{Összegzés és előretekintés}

Tanulmányunkban áttekintettük a digitális oktatás jelenlegi helyzetét, bemutattuk a nemzetközi gyakorlatának legaktuálisabbnak látszó témáit, az oktatásinformatika hangsúlyának változásait, a fejlődés néhány lehetséges irányát és trendjeit. Kutatásunk alapján megállapíthatjuk, hogy a közeli jövőben leginkább érdeklődésre számot tartó témakörök az oktatásinformatikában a következők: 
- az oktatási robotika alkalmazása, továbbfejlesztése;

- a kiterjesztettvalóság-alkalmazások;

- a digitális történetmesélés;

- a kódolás tanulása játékos (Scratch) és valódi, kézzel fogható (Micro:bit, LEGO-Robotika és más) eszközök felhasználásával;

- a számítógépes gondolkodás gyakorlatba való átültetésének kérdései;

- az SNI diákok IKT- és más kompetenciáinak fejlesztési lehetőségei a korszerű digitális technológiák bevonásával.

A húsz évvel korábbi tanulmányunkban (Fehér, 1999) felsoroltunk néhány jövőre vonatkozó jóslatot, amelyek akkor talán valamelyest fantasztikusnak tűntek, mégis napjainkra a Mars utazást kivéve mind megvalósultak. Milyen jóslatokat tehetünk ma a következő húsz évre? Ezúttal is megfogalmazunk néhány jóslatot, évszámok nélkül. Elképzelhető, hogy bekövetkezik 1. a nyelvtudás fontosságának csökkenése - a fordítóprogramok rendkívül gyors fejlödése következményeként; 2 . a papíralapú tankönyvek teljes eltűnése; 3 . a felsőoktatás erőteljesen online alapokon nyugvóvá válása; 4 . a robotika és az automatizálás fejlődése miatt jelentős mértékű munkanélküliség; és végül a legfantasztikusabbnak tünő lehetőség 5 . Elon Musk szerint akár 5 éven belül jöhetnek az emberi agyba ültethető chipek.

Jóllehet, a technológiai fejlődés lassulása nem érzékelhető, mégis azon a véleményen vagyunk, hogy rövidtávon (az elkövetkező öt évben) nem a technikai újdonságoké lesz a föszerep, hanem a humán tényezőké. A tanulmányban bemutatott példákból az is látható, hogy a fejlődés egyik humán kulcskomponense a tanárok folyamatos felkészítése, tovább- és önképzése annak érdekében, hogy megfelelhessenek a 21. századi oktatás elvárásainak. A másik tényező pedig a diákok (digitális) tanulási képességeinek, az önszabályozó tanulásnak, a kritikus gondolkodásnak magasabb szintre emelése, amely lehetővé teszi annak a sokat emlegetett ideának a megvalósulását, amikor a tanárok és diákok közös munkájának eredményeként hatékonyabbá, élményszerủbbé és felhasználhatóbbá válik a megszerzett tudás.

\section{Irodalom}

Aknai, D. O. \& Fehér, P. (2019). Kalandozások robotméhecskével-problémamegoldás, gondolkodásfejlesztés padlórobotokkal. Debreceni Egyetemi Kiadó - IKT MasterMinds Kutatócsoport.

Alimisis, D. (2013). Educational Robotics: new challenges and trends. Themes in Science and Technology Education, 6(1), 63-71.

Austin, J., Baker, H., Ball, T., Devine, J., Finney, J., De Halleux, P., Hodges, S., Moskal, M. \& Stockdale, G. (2020). The BBC micro:bit - From the U.K. to the World. Communications of the ACM, 63(3), 62-69. doi: 10.1145/3368856

Balanskat, A., \& Garoia, V. (2010). Netbooks on the rise: European overview of national laptop and netbook initiatives in schools. European Schoolnet, Brussels. 
http://static.acer.com/up/Resource/Acer/Education/docs/20110301/netbooks_ on_the_rise.pdf (2020.04.30.)

Balanskat, A. \& Engelhardt, K. (2014). Computing our future. Computer programming and coding - Priorities, school curricula and initiatives across Europe European Schoolnet. http://www.allyouneediscode.eu/documents/12411/14644/Coding+ initiative+report-European+Schoolnet-October2014.pdf/66475be8-cc31-429ca5cc-32767366c8c2 (2020.04.30.)

Balanskat, A. \& Engelhardt, K. (2015). Computing our future. Computer programming and coding - Priorities, school curricula and initiatives across Europe European Schoolnet. http://www.eun.org/documents/411753/817341/ Computing+our+future_final_2015.pdf/d3780a64-1081-4488-85496033200e3c03 (2020.04.30.)

Beauchamp, G. \& Hillier, E. (2014). An Evaluation of Ipad Implementation Accross a Network of Primary Schools in Cardiff, BERA conference. School of Education, Cardiff Metropolitan University.

Beland, L. P. \& Murphy, R. (2015). Ill Communication: Technology, Distraction E Student Performance. CEP Discussion Paper, 1350. London School of Economics. http://cep.lse.ac.uk/pubs/download/dp1350.pdf (2020.04.25)

Bers, M. (2008). Blocks to Robots: Learning with Technology in the Early Childhood Classroom. Teachers College Press.

Bers, M.U. (2018). Coding as a Playground: Programming and Computational Thinking in the Early Childhood Classroom. Routledge Press.

Burden, K., Hopkins, P., Male, T., Martin, S. \& Trala, Ch. (2012). iPad Scotland Final Evaluation Report. Faculty of Education, The University of Hull. https:// digitalteachingandlearning.files.wordpress.com/2012/12/ipad-scotlandevaluation.pdf (2020.04.25.)

Clark, W. \& Luckin, R. (2013). 'What the research says' - iPads in the Classroom, London Knowledge Lab. https://digitalteachingandlearning.files.wordpress. com/2013/03/ipads-in-the-classroom-report-lkl.pdf (2020.04.30.)

Czékmán, B. \& Fehér, P. (2017). A számítógéppel támogatott tanítás és tanulás története a közoktatásban Magyarországon (1983-2016). Képzés és Gyakorlat, Training and Practice 15(1-2), 45-66. https://doi.org/10.17165/TP.2017.1-2.3, 45-66.

Czékmán, B., Aknai, D. O. \& Fehér, P. (2017a). A tartalom-előállítás lehetőségei a virtuális valóság (VR) és a kiterjesztett valóság (AR) oktatási célú alkalmazásai esetében. In Hülber, L. \& Tamásné Fekete, A. (Eds.), II. Oktatástervezési és Oktatás-informatikai Konferencia: absztraktkötet (pp. 39-40). Líceum Kiadó.

Czékmán, B., Aknai, D.O., Fehér, P. (2017b): Digitális történetmesélés „kiterjesztett valóság" (AR) alkalmazások segítségével. In Magyari, S., Bartha, K. \& Balogh B. (Eds.), Oktatás határhelyzetben (pp. 16-22.). Partium Kiadó.

Czékmán, B. \& Kiss, J. (2018). Digitális eszközök használata az osztálytermekben. Egy BBC micro:bites projekt tapasztalatai. Educatio, 27(1), 111-120. 
Czékmán, B. (2019). Tablettel támogatott oktatás: Nagyvolumenü nemzetközi és hazai kezdeményezések. In Juhász, E. \& Endrődy, O. (Eds.): Oktatás Gazdaság - Társadalom (pp. 477-489). Debreceni Egyetem, Magyar Nevelés- és Oktatáskutatók Egyesülete (HERA).

Davis, L. (2020). Digital Learning: What to Know in 2020. Evolving Ed. https://www. schoology.com/blog/digital-learning (2020.04.30.)

de Jager, A., Fogarty, A., Tewson, A., Lenette, C. \& Boydell, K. M. (2017). Digital storytelling in research: A systematic review. The Qualitative Report, 22(10), 2548-2582. http://nsuworks.nova.edu/tqr/vol22/iss10/3 (2020.04.30).

Dringó-Horváth, I. (2018). IKT a tanárképzésben: a magyarországi képzőhelyek tanárképzési moduljában oktatók IKT mutatóinak mérése. Új Pedagógiai Szemle, 68(9-10), 13-41.

Dringó-Horváth, I. \& Gonda, Zs. (2018). Tanárjelöltek IKT-kompetenciájának jellemzői és fejlesztési lehetőségei. Képzés és Gyakorlat, 16(2), 21-47.

Fehér, P. (1999). Számítógépek az oktatásban a harmadik évezred küszöbén. Új Pedagógiai Szemle, 49(7-8), 181-189.

Ellis, Y., Daniels, B. \& Jauregui A. (2010). The effect of multitasking on the grade performance of business students. Research in Higher Education Journal, 8, 1-10.

Feher, P. (2008). Towards effective student-centered, constructivist learning: Build Your Own Digital Story! (A Hungarian Case Study). In Luca, J. \& Weippl, E. (Eds.), Proceedings of ED-MEDIA 2008-World Conference on Educational Multimedia, Hypermedia \& Telecommunications (pp. 2364-2367). Association for the Advancement of Computing in Education (AACE). https://www.learntechlib. org/primary/p/28695/ (2020.04.30.)

Fehér, P. (2010) „Digitális mesék - Digitális papíron”. In Kőrösné Mikis Márta (Ed.), IKT-MOZAIK: Kézikönyv pedagógusoknak a számitógép tanórai alkalmazásához (pp. 184-189). Oktatáskutató és Fejlesztő Intézet (OFI) http://ikt.ofi.hu/ikt/wpcontent/uploads/ikt-mozaik.pdf (2020.04.30.)

Fehér, P. \& Hornyák, J. (2011). 8 óra pihenés, 8 óra szórakozás, avagy a Netgeneráció 2010 kutatás tapasztalatai. In Ollé, J. (Ed.), III. Oktatás Informatikai Konferencia Tanulmánykötet (pp. 101-110). ELTE Eötvös Kiadó.

Fehér, P. (2015). Kompetenciafejlesztés kisiskolásoknak digitális történetmeséléssel. In Námesztovszki, Zs. \& Vinkó, A. (Eds.) XXI. Multimédia az oktatásban és II. IKT az oktatásban konferencia (pp. 240-241) Újvidéki Egyetem Magyar Tannyelvű Tanítóképző Kar. http://www.mmo.njszt.hu/Kiadvanyok/2015/ MMO2015_Proceedings.pdf (2020.04.30.)

Fehér, P., Czékmán, B., \& Aknai, D. O. (2016a). Interaktív AR alkalmazások használata és készítése tanórán és azon túl. In Fehér, P. \& Aknai, D. O. (Eds.), I. Mobil eszközök az oktatásban konferencia: Program, elöadás-összefoglalók (pp. 54). Debreceni Egyetemi Kiadó. 
Fehér, P., Aknai, D. O. \& Czékmán, B. (2016b). Digitális történetek és a kiterjesztett valóság a „Digitális mesefal” projektben. In Czékus, G. \& Borsos, É. (Eds.), A Magyar Tannyelvü Tanitóképző Kar 2016-os tudományos konferenciáinak tanulmánygyüjteménye [Zbornik radova naučnih konferencija Učiteljskog fakulteta na madarskom nastavnom jeziku 2016]: X. nemzetközi tudományos konferencia, V. módszertani konferencia, III. IKT az oktatásban konferencia, (pp. 375-381). Újvidéki Egyetem Magyar Tannyelvü Tanítóképző Kar.

Fehér, P. \& Aknai, D. O. (2017a). Computational Thinking in Problem-Solving: A Theoretical Overview. In Vidákovich, T. \& Füz, N. (Eds.), 16th Conference on Educational Assessment, Programme and Abstracts (pp. 30). Szegedi Tudományegyetem Neveléstudományi Doktori Iskola.

Fehér, P. (2017b). Digitális történetmesélés a természettudományos oktatásban. In Kissné Zsámboki, R. \& Horváth, Cs. (2019, Eds.), Diverzitás a hazai és nemzetközi neveléstudományi kutatásokban és a pedagógiai gyakorlatban: X. Képzés és Gyakorlat Nemzetközi Neveléstudományi Konferencia Absztraktkötet (pp. 111). ["Diversity in National and International Researches in Educational Sciences and Pedagogical Practice" 10th Training and Practice International Conference on Educational Sciences Abstracts] Soproni Egyetem Kiadó.

Fehér, P. (2017c). Több, mint kódolás - a kreativitás fejlesztése Micro:bit-tel. In Aknai, D. O. \& Fehér, P. (Eds.), II. Mobil eszközök az oktatásban konferencia. Program Elöadás-összefoglalók (pp. 32). Debreceni Egyetemi Kiadó. (

Fehér, P. (2018a). Helyzetelemzés a magyar oktatás digitális átállásának helyzetérōl és lehetöségeiröl, különös tekintettel az oktatás-és tanulásszervezés kihívásaira (pp. 1-53). Kézirat, készült a Digitális Módszertani Központ (DPMK) megbízásából.

Fehér, P. (2018b). Mi van a „Tiger Leap” mögött? Az észt modell gyakorlatba való átültetésének bemutatása (pp. 1-23). Kézirat, készült a Digitális Módszertani Központ (DPMK) megbízásából.

Fehér, P. (2018c). Lépésváltás az Egyesült Királyságban: IKT-tól a számitógépes gondolkodás felé (pp. 1-20). Kézirat, készült a Digitális Módszertani Központ (DPMK) megbízásából.

Fehér, P. (2018d). A számítógépes gondolkodás alkalmazásának gyakorlati lehetőségei - fejlesztés Micro:bit-tel. In Oktatás, gazdaság, társadalom: HuCER 2018 Absztraktkötet (pp. 59). Magyar Nevelés- és Oktatáskutatók Egyesülete, Hungarian Educational Research Association (HERA).

Fehér, P. \& Aknai, D. O. (2019). Wandering Robots in Hungarian Primary Schools: a Case Study. EERA - ECER Conference, Hamburg, Germany. https://eera-ecer. de/ecer-programmes/conference/24/contribution/49025/ (2020.04.30.)

Ferdig, R. E., Gandolfi, E. \& Immel, Z. (2018). Educational Opportunities for Immersive Virtual Reality. In Voogt, J., Knezek, G., Christensen, R., \& Lai KW. (Eds.), Second Handbook of Information Technology in Primary and Secondary Education (pp. 955-966). Springer International Handbooks of Education. 
Füzi, I. (2018). Az oktatási kihívások pszichológiai vonatkozásai. Interjú Szabó Évával. Új Apertúra, 13(2). https://doi.org/10.31176/apertura.2018.2.2

Global Augmented Reality (2019). https://www.prnewswire.com/news-releases/ global-augmented-reality-ar-and-virtual-reality-vr-market-in-healthcaremarketto-reach-11-14-billion-by-2025--300831306.html. (2020.04.30).

Horváth, Á. (2018). A teljes magyar oktatási rendszer digitális átalakitása projektek helyett egységes szabályozás! XX: Közoktatási Szakértői Konferencia, Hajdúszoboszló. https://kiadvany.suliszerviz.com/images/kiadvany2018/H\%C3\%81_ jav/Hajd\%C3\%BAszoboszl\%C3\%B3_H\%C3\%81_20181107.pdf (2020.04.30.)

Horváth, Á. (2019). Mi jön a Digitális Oktatási Stratégia után? XXI. Közoktatási Szakértői Konferencia, Hajdúszoboszló. https://kiadvany.suliszerviz. com/images/kiadvany2019/XXI_Plen/cs\%C3\%BCt/Horv\%C3\%A1th\%20 \%C3\%81d\%C3\%A1m_nem_an.pdf (2020.04.30.)

Horváth, L., Misley, H., Hülber, L., Papp-Danka, A., M. Pintér, T. \& Dringó-Horváth, I. (2020). Tanárképzők digitális kompetenciájának mérése - a DigCompEdu adaptálása a hazai felsőoktatási környezetre, Neveléstudomány, 8(2), 5-25. http:// nevelestudomany.elte.hu/downloads/2020/nevelestudomany_2020_2_5-25.pdf

Kiss, R. (2015). Robotika a közoktatásban. Gradus, 2(2), 81-93.

Koltay, T. (2011). Kérdések és válaszok az írástudás új formáiról. Anyanyelvpedagógia, 4(3), 3-25.

Koltay, T. (2016). Médiaműveltség, digitális bennszülöttek: a mítoszok vége? Iskolakultúra, 26(1), 102-109.

Kriskó, E. (2017). Új kihívások a virtuális és a kiterjesztett valóságok korában. Médiakutató, 18(1-2), 125-137.

Kucuk, S., \& Sisman, B. (2020). Students' attitudes towards robotics and STEM: Differences based on gender and robotics experience. International Journal of Child-Computer Interaction, 1(1), 1-19. https://www.sciencedirect.com/ science/article/abs/pii/S2212868920300039 (2020.04.30.)

Lanszki, A. (Ed., 2017). Digitális történetmesélés a nevelési-oktatási folyamatban. Líceum Kiadó.

MDOS (Magyarország Digitális Oktatási Stratégiája). Retrieved from https://www. kormany.hu/download/0/cc/d0000/MDO.pdf (2020.04.30.)

Mathew, L. (2015). The Effect of Multitasking and Grade Performance of Undergraduate Nursing Students. Open Access Library Journal, 2(11), 1-4. https://doi.org/10.4236/oalib.1102059.

Molnár Gy., Turcsányi-Szabó, M. \& Kárpáti, A. (2020). Digitális forradalom az oktatásban - Perspektívák és dilemmák. Magyar Tudomány, 181(1), 59-67.

Papert, S. (1981). Észrengés. A gyermeki gondolkodás titkos útjai. Számalk Kiadó.

Pasaréti, O. (2009). Mesél a számítógép. Interaktív mesekészítés óvodás és kisiskoláskorban. Oktatás-Informatika, 1(2), 76-83. 
Prensky, M. (2001). Digital Natives, Digital Immigrants, Part 1, On the Horizon, NCB University Press, 9(5), 1-6.

Radianti, J., Majchrzak, A. T., Fromm, J., \& Wohlgenannt, I. (2019). A systematic review of immersive virtual reality applications for higher education: Design elements, lessons learned, and research agenda. Computers E Education, 147: 103778. https://doi.org/10.1016/j.compedu.2019.103778 (2020.04.30.)

Resnick, M. (2015). Coding as the New Literacy. http://serious-science.org/codingas-new-literacy-1546 (2020.04.30.)

Resnick, M. \& Siegel, D. (2015). A Different Approach to Coding. How kids are making and remaking themselves from Scratch. https://brightthemag.com/adifferent-approach-to-coding-d679b06d83a (2020.04.30.)

Royal Society. (2012). Shutdown or Restart? The way forward for computing in UK schools. https://royalsociety.org/-/media/education/computing-inschools/2012-01-12-computing-in-schools.pdf (2020.04.30)

Royal Society. (2017). After the reboot: Computing education in UK schools. https:// royalsociety.org/ /media/policy/projects/computing-education/computingeducation-report.pdf (2020.04.30)

Sallai, É. (2016). Tanítás és robotprogramozás LEGO-val. Új Köznevelés, 72(5-6), $22-25$.

Sullivan, A. \& Bers, M.U. (2012). Gender differences in kindergarteners' robotics and programming achievement. International Journal of Technology and Design Education, 23(3) https://doi.org/10.1007/s10798-012-9210-z

Tilhou, R., Taylor, V. \& Crompton, H. (2020). 3D Virtual Reality in K-12 Education: A Thematic Systematic Review. In Yu, S., Ally, M. \& Tsinakos, A. (Eds.), Emerging Technologies and Pedagogies in the Curriculum (pp. 169-184). Springer Nature. https://doi.org/10.1007/978-981-15-0618-5_10.

Tóth-Mózer, Sz. \& Kárpáti, A. (2016). A digitális kompetencia kognitív dimenziója és összefüggésrendszere egy empirikus kutatás tükrében. Magyar Pedagógia, 116(2), 121-150.

Tóth-Mózer, Sz. (2017). Digitális nemzedék a tanulási folyamatban - Középiskolások internethasználati és tanulási preferenciái, énképe és digitális kompetenciája. Publikált doktori disszertáció. Eötvös Kiadó.

Tóth-Mózer, Sz. (2018). Digitális tanulói jellemzők és hatékony tanulási szokások. Új Apertúra, 13(2). https://doi.org/10.31176/apertura.2018.2.3

Turcsányi-Szabó, M. \& Pasaréti, O. (2010). The "computer" tells a story? In Proceedings. of Constructionism (pp. 26). Comenius University, Bratislava in association with The American University of Paris, Paris, France.

Wing, J. M. (2006). "Computational Thinking," Communications of the Association for Computing Machinery Viewpoint, 49(3), 33-35.

https://doi.org/10.1145/1118178.1118215. 
Wu, J., \& Chen, D-T. V. (2019). A systematic review of educational digital storytelling. Computers \& Education, 147. https://www.sciencedirect.com/science/article/ abs/pii/S0360131519303367 (2020.04.30.)

\section{Weboldalra hivatkozás}

Digitális Témahét. Retrieved from: https://igitalistemahet.hu/temahetrol (2020.04.30.)

Digitális történetmesélés-Digital Storytelling (DS) https://tka.hu/nemzetkozi/6577/ digitalis-tortenetmeseles Tempus Közalapítvány honlapja. (2020.04.30.) 


\section{Fehér, P.}

\section{Twenty years later - the actual aspects and trends in digital education worldwide}

In this paper - reflecting to our 20 years old paper - we provide a wide overview of the current aspects of the digital education. We pay close attention to the following topics: mobile learning, coding-computational thinking-robotics, digital storytelling, media literacy and critical thinking. Beyond the rich presentation of the results of international research and practice, we highlight the accomplishments and challenges of the digital education in Hungary.

Keywords: digital education, mobile learning, coding, digital storytelling, STEM, trends

Fehér Péter: https://orcid.org/0000-0003-0246-7133 